Андрій Васильович Андрушко, кандидат юридичних наук, доцент, доцент Ужгородського національного університету*

ORCID: 0000-0002-7735-7898

\title{
ВІКТИМОЛОГІЧНА ХАРАКТЕРИСТИКА ЖЕРТВ НЕЗАКОННОГО ПОЗБАВЛЕННЯ ВОЛІ АБО ВИКРАДЕННЯ ЛЮДИНИ
}

Як відомо, неправомірна, легковажна або інша віктимна поведінка особи може справити певний стимулюючий вплив на схильних до правопорушень осіб, підштовхуючи їх до вчинення кримінально караних діянь.

Вивчення віктимологічних аспектів окремих злочинів допоможе переглянути і вдосконалити систему заходів запобігання відповідним посяганням шляхом профілактичного впливу на потенційних жертв. Не $\epsilon$ винятком і злочини проти волі, честі та гідності особи, зокрема й незаконне позбавлення волі або викрадення людини (ст. 146 Кримінального кодексу України).

Попри певну увагу, приділену вітчизняними кримінологами (зокрема, В.С. Батиргареєвою, В.В. Голіною, О.В. Лисодєдом), проблемним питанням запобігання незаконним позбавленням волі або викраденням людей, відповідна проблематика залишається малорозробленою та перспективною для подальших досліджень. Стосується сказане й розроблення віктимологічної характеристики жертв даного злочину.

Мета статті - на підставі аналізу доступної емпіричної бази надати віктимологічну характеристику жертв незаконного позбавлення волі або викрадення людини.

Автором проаналізовано 370 кримінальних справ (проваджень) про незаконне позбавлення волі або викрадення людини, розглянутих судами України протягом 2010-2018 років. Узагальнено дані стосовно 447 жертв вказаного злочину.

Розглядуване діяння в більшості вивчених нами випадків було вчинено щодо однієї особи. Зазначимо при цьому, що множина потерпілих більш характерна для такої форми аналізованого злочину, як викрадення людини, тоді як незаконне позбавлення волі без їі викрадення вчиняється, як правило, щодо однієї особи. Водночас слід зауважити, що іноді розглядуване діяння повторно вчиняється стосовно різних потерпілих. Йдеться насамперед про досить поширені (виявлено сім відповідних проваджень) випадки протиправного утримування наркоманів та хронічних алкоголіків у фіктивних реабілітаційних центрах під приводом їх реабілітації від наркотичної чи алкогольної залежності. Так, наприклад, Орджонікідзевський районний суд м. Запоріжжя у липні 2018 р. засудив учасників організованої групи, які протягом липня 2016 - вересня 2017 р. $з$ корисливих мотивів, під приводом реабілітації від наркотичної та алкогольної залежності, викрали і незаконно позбавили волі 17 осіб. Учасники організованої групи підшукували людей з числа наркозалежних та хронічних алкоголіків, проводили перемовини з їхніми родичами, обіцяли їм повну добровільність запланованих заходів реабілітації, повноцінний раціон харчування, можливість на власний розсуд у будьякий момент залишити хворим центр у разі незгоди з умовами та методами реабілітації. При цьому умовою перебування «реабілітантів» в таких центрах була грошова винагорода, яку необхідно було сплачувати в якості пожертви в розмірі від 1200 до 3500 грн на місяць. Всупереч запевненням злочинців у благородності їхніх намірів, хворих позбавили можливості самостійно залишити заклад, здійснювали за ними цілодобовий нагляд та охорону, змушували працювати, годували зіпсованими продуктами, тимчасово взагалі позбавляли харчування, застосовували тілесні покарання за будь-який непослух, систематично принижували їхню людську гідність ${ }^{1}$.

Серед жертв розглядуваного злочину 69,6 \% - особи чоловічої статі, 30,4 \% - жіночої. При цьому варто зазначити, що поміж жертв незаконного позбавлення волі, не пов’язаного з їх викраденням, кількість жінок

(C) А.В. Андрушко, 2019

* Andriy Andrushko, Ph.D. in Law, Associate professor, Associate professor of Uzhgorod National University 
та чоловіків майже однакова. Водночас інші дослідники вказують на меншу частку осіб жіночої статі серед жертв аналізованого злочину (до 20-22 \%)르. На підставі вивчення доступної емпіричної бази можна також виокремити групу розглядуваних діянь, у яких жінки становлять майже 100 \% жертв - незаконне позбавлення волі або викрадення людини, вчинюване в сімейно-побутовій сфері.

Розподіл потерпілих від аналізованого злочину залежно від їх віку виглядає таким чином: до 18 років 14,1 \% (з них малолітні - 9,8 \%), від 18 до 30 років - 29,4 \%, від 30 до 40 років - 33,7 \%, від 40 до 50 років $16,3 \%$, понад 50 років - 6,5\%. Як бачимо, найбільша кількість жертв незаконного позбавлення волі або викрадення людини серед осіб у віці від 30 до 40 років, однак чисельність осіб у віці від 18 до 30 років є ненабагато меншою. Кожен десятий потерпілий від вказаного злочину - малолітня особа.

Лише двоє із 447 (0,4 \%) потерпілих від розглядуваного посягання не були громадянами України. Йдеться про осіб, які мали громадянство Узбекистану та Індії. В одному із випадків винні, діючи 3 корисливих мотивів, цілеспрямовано вибрали жертвою підприємця-іноземця (громадянина Індіï), розраховуючи на його незахищеність як особи, що перебуває на «чужій» території ${ }^{3}$.

Віктимологічний інтерес становлять також дані про сімейний стан жертв незаконного позбавлення волі або викрадення людини. Відповідну інформацію вдалося отримати лише стосовно 152 потерпілих. Тільки 29 \% жертв вказаного посягання перебували у шлюбі (офіційно зареєстрованому або фактичному). У розглядуваному контексті необхідно підкреслити, що аналізоване діяння нерідко вчиняється саме у сімейно-побутовій сфері. При цьому є підстави стверджувати, що більшість таких злочинів залишаються латентними ${ }^{4}$

Інформацію про освітній рівень потерпілих вдалося отримати лише стосовно 124 осіб. Поміж жертв незаконного позбавлення волі або викрадення людини 6,4 \% осіб мали неповну середню освіту, 49,2 \% загальну середню, 33,9 \% - середню спеціальну, 10,5 \% - вищу.

Чималий інтерес становлять дані, що ілюструють професійну приналежність жертв розглядуваного діяння. На момент вчинення щодо них злочину 41,8 \% потерпілих ніде не працювали або мали лише сезонний заробіток, 39,4 \% - працювали, 11,6 \% - були учнями, 2,9 \% - пенсіонерами, 4,3 \% - займались підприємницькою діяльністю. Отримані результати не підтверджують дані, що їх наводять інші дослідники; зокрема, кардинально іншими є цифри, які стосуються частки підприємців серед жертв даного злочину (за деякими оцінками, кількість останніх сягає $34 \% 5,40 \% 6,58,6 \% 7$ і навіть $67 \% \%^{8}$ ). Поміж працевлаштованих - представники найрізноманітніших професій: правоохоронці, військові, прикордонники, державні службовці, вчителі, охоронці й сторожі, робітники, водії тощо. Варто також зазначити, що окремі особи стали жертвами незаконного позбавлення волі або викрадення людини на своєму робочому місці. Наприклад, Першотравневий районний суд м. Чернівці 12 квітня 2013 р. засудив підприємця, котрий з метою з'ясування у свого найманого працівника причин нестачі, яка виникла на підприємстві, спершу заподіяв йому легкі тілесні ушкодження, а потім прив'язав до металевої основи стелажа, позбавивши чоловіка можливості вільно залишити приміщення складу, де він не бажав перебувати 9.

До моменту вчинення розглядуваного злочину переважна більшість (орієнтовно 60 \%) потерпілих були так чи інакше знайомі із винними (перебували з ними в родинних, подружніх, трудових, приятельських чи інших відносинах, були односельчанами, сусідами або ж ледь знайомими). Зазначимо, що незнайомі із винними особи найчастіше ставали жертвами незаконного позбавлення волі або викрадення людини, вчиненого 3 корисливих мотивів.

Аналіз емпіричної бази допоміг також зібрати та систематизувати інформацію, що стосується часу доби, коли людину було незаконно позбавлено волі або викрадено: 13,9 \% осіб стали жертвами розглядуваного злочину зранку, $31,8 \%$ - удень, 37,3 \% - увечері, $17 \%$ - у нічний час.

Жертвами незаконного позбавлення волі люди стають у місцях, в яких вони перебували (приміром, всупереч їхньому бажанню їх не випускають $з$ помешкання чи автомобіля, силою заштовхують до підвального приміщення будинку тощо). Більшістю викрадених людей винні заволоділи на вулиці, у помешканні потерпілого чи на прилеглій до нього території. У низці випадків злочинці блокували особі проїзд дорогою, після чого, дочекавшись, коли потерпілий зупинить своє авто і вийде з нього, застосовували фізичне насильство $i$ поміщали його до іншого автомобіля, надалі перевозячи до певного місця. Місцями викрадення людей були також території підприємств, установ та організацій, сільськогосподарські поля, автомобілі, автовокзали, кафе, магазини тощо.

3 метою незаконного позбавлення ії волі до особи нерідко застосовується фізичне насильство. Що ж стосується заволодіння людиною при їі викраденні, то фізичне насильство тут має місце як правило. Часто фізичне насильство поєднується з насильством психічним або ж з обманом. Наприклад, один із учасників групи осіб, що діяла на замовлення чоловіка, якому потерпіла доводилася колишньою дружиною, звернувся до останньої, повідомивши їй неправдиву інформацію про те, що він не місцевий мешканець, 3 проханням підійти до автомобіля і пояснити, де у Черкасах знаходиться вулиця Ільїна, після чого разом $з$ іншим співучасником жінку схопили з обох боків під руки і, діючи проти іiі волі, застосовуючи фізичну силу, примусово заштовхали до салону автомобіля ${ }^{10}$. При незаконному позбавленні людини волі чи їі викраденні використання вогнепальної зброї трапляється порівняно рідко. Причому у разі вчинення незаконного позбавлення людини волі без іiі викрадення вогнепальна зброя застосовується вкрай рідко. Для захоплення людини та подолання опору при ііі викраденні вогнепальна зброя використовувалась частіше - орієнтовно у 6 \% випадків (йдеться, як правило, про погрози ііі застосування у разі, якщо потерпіла особа чинитиме спротив). Цікаво, що двом потерпілим, як виявилось згодом, злочинці погрожували іграшковим пістолетом ${ }^{11}$. Ще до 2,5 \% 
потерпілих застосовувались газові балончики, до 2,3\% - травматична, пневматична чи газова зброя, до $1,3 \%$ - холодна зброя, до 3,1 \% - наручники, до $1,1 \%$ - електрошокові пристрої.

Після силового захоплення викрадених людей переміщають до певного місця, як правило, автомобілем. При цьому звертає на себе увагу той факт, що частіше (орієнтовно у 60 \% випадків) потерпілих поміщають не в салон автомобіля, а в його багажник. Вочевидь, робиться це передовсім для позбавлення особи можливості орієнтуватися у місцевості, а також з метою ііі приниження. Так само досить поширеною є практика, коли потерпілій особі, поміщеній в салон автомобіля, надягають на обличчя шапку чи іншим чином закривають очі (зокрема, для того, аби жертва не змогла пізніше впізнати своїх викрадачів). В одному випадку зв'язаного потерпілого відвезли до села, де зачинили в погребі, на гужовій підводі12. Зазначимо також, що викрадених новонароджених чи малолітніх дітей нерідко переміщають не за допомогою автомобіля, а переносять на руках, силою або шляхом обману затягують до сусіднього будинку тощо.

Викрадених людей переміщають, як правило, на невеликі відстані - здебільшого в межах одного району (наприклад, везуть на околицю населеного пункту, до найближчого лісу чи водойми). Лише в кількох випадках жертв розглядуваного злочину переміщали за кордон. Так, наприклад, Марківський районний суд Луганської області засудив групу осіб, які, діючи за грошову винагороду, силою посадили потерпілого на заднє сидіння автомобіля, після чого, привізши його до лісосмуги, де проходить межа державного кордону між Україною та Росією, перевели на сторону Російської Федерації і передали там трьом невідомим особам ${ }^{13}$.

Вивчення емпіричної бази засвідчило, що у більшості випадків потерпілі від незаконного позбавлення волі або викрадення людини не чинили винним активного опору. Пов'язано це з багатьма чинниками: раптовістю та інтенсивністю вчинюваного посягання, слабкою фізичною підготовкою потерпілих, їхнім малолітнім чи старечим віком, явною чисельною перевагою нападників, демонстрацією винними зброї і погрозами застосувати іiі у разі будь-якого спротиву, впевненістю потерпілих у тому, що особи, які їх затримують, $\epsilon$ працівниками правоохоронних органів (тоді, коли злочинці видавали себе за таких) тощо. В окремих випадках винні спершу приводили потерпілих у безпорадний стан, тим самим унеможливлюючи їхній опір, а вже потім незаконно позбавляли їх свободи. Наприклад, Вишгородський районний суд Київської області у вересні 2018 р. засудив чоловіка, який з метою безоплатного проживання в орендованій квартирі вирішив незаконно позбавити їі власницю волі. За допомогою доданого до томатного соку метадону він домігся того, що жінка втратила свідомість, після чого помістив її в салон автомобіля і перевіз з Вишгорода до села Савенки 14. Орієнтовно 10 \% жертв розглядуваного злочину намагалися чинити винним активний опір, який, утім, здебільшого не був ефективним. В окремих випадках потерпілим вдавалося звільнитися на певний час, однак злочинці наздоганяли жертв і врешті долали їхній спротив. І лише в поодиноких випадках опір був ефективним і привів до звільнення потерпілого чи припинення ним вчинюваного протиправного посягання. Варто також зазначити, що іноді припинити незаконне позбавлення волі або викрадення людини намагаються родичі потерпілих, їхні знайомі, а подеколи й звичайні перехожі; однак аналіз доступної емпіричної бази засвідчив, що відповідні дії вказаних осіб, як правило, не досягали очікуваного результату.

Здійснене дослідження засвідчило, що мінімальний та максимальний проміжок часу, протягом якого утримували жертв розглядуваного злочину, дуже різняться - від 4-5 хвилин ${ }^{15}$ до понад 11 місяців $16.17,2 \%$ потерпілих утримували від кількох хвилин до однієї години, 29,3 \% - від 1 до 3 годин, 15,4 \% - від 3 до 6 годин, 6,5\% - від 6 до 12 годин, 6,5\% - від 12 до 24 годин, 5,8\% - від 1 до 3 діб, 2,9\% - від 3 до 7 діб, 7,8 \% від 7 діб до 1 місяця, 4 \% - від 1 до 3 місяців, 2,9\% - від 3 до 6 місяців, 1,6 \% - понад 6 місяців. Таким чином, незаконне позбавлення волі потерпілої особи у більшості випадків триває недовгий період часу - від кількох хвилин до кількох годин. Переважно цього часу винним вистачає для того, аби досягти мети, 3 якою вони вчиняють дане посягання (або ж навпаки (що трапляється набагато рідше) - усвідомити, що досягти запланованого результату з певних причин (приміром, через реальну загрозу затримання правоохоронцями) не вдасться). Кожну четверту жертву розглядуваного діяння утримували понад добу. Аналіз матеріалів кримінальних проваджень засвідчив, що найтриваліші строки незаконного позбавлення волі характерні здебільшого для випадків протиправного утримування наркоманів та хронічних алкоголіків у фіктивних реабілітаційних центрах під приводом їх реабілітації від наркотичної чи алкогольної залежності.

Жертв незаконного позбавлення волі або викрадення людини засуджені за вчинення цього злочину утримували в найрізноманітніших місцях. Найчастіше таким місцем є житлове приміщення (кімната, квартира, будинок), підвал або погріб, лісопосадка, пустир. Варто при цьому вказати на відмінності щодо місця утримання потерпілої особи залежного від того, була вона викрадена чи незаконно позбавлена волі без попереднього викрадення. Оскільки умисел на незаконне позбавлення волі без попереднього викрадення людини значно частіше виникає раптово, то й місце утримання потерпілого довго вибирати не доводиться (ним здебільшого є житлове або підвальне приміщення). Викрадених людей після переміщення 3 того місця, де вони перебували, у те, де вони не бажали перебувати, злочинці утримували в набагато різноманітніших місцях. Такими місцями часто є не тільки житлові або підвальні приміщення, а й автомобілі (іноді потерпілих возять 3 місця до місця, не відпускаючи), гаражі, господарські чи підсобні приміщення, кладовища, лісосмуги, поля, береги водойм, малолюдні околиці населених пунктів, пустирі тощо. Важливо підкреслити, що в більшості випадків викрадення людини злочинці насамперед прагнуть перемістити жертву у безлюдне місце, де пред’явити їй свої вимоги, заподіяти тілесні ушкодження тощо. Саме тому чимало винних не сприймає саме по собі заволодіння людиною та її переміщення як злочин; основною метою відповідного вчинку здебільшого є «3'ясувати відносини» без зайвих свідків. Водночас зазначимо, що деяких потерпілих (як правило, тих, 
яких викрали, керуючись корисливим мотивом) тримали в спеціально пристосованому для тривалого утримування приміщенні, куди доставляли після силового захоплення жертви. Так, наприклад, група осіб, засуджених Ленінським районним судом м. Запоріжжя, маючи умисел на викрадення та незаконне позбавлення волі заможного чоловіка з метою отримання від нього викупу за звільнення, заздалегідь орендувала у місті будинок, в підвалі якого встановила спеціальну клітку для незаконного утримування людини ${ }^{17}$.

Незаконне утримування особи зазвичай супроводжується заподіянням їй різної тяжкості тілесних ушкоджень, катуванням, погрозами фізичною розправою, приниженням людської гідності. Незаконно позбавлених волі чи викрадених людей нерідко утримують у темному, холодному та сирому приміщенні (підвалі чи погребі), без світла, їжі та води, тим самим виснажуючи організм (особливо ж у разі незаконного позбавлення волі, здійснюваного протягом тривалого часу); часто їх зв’язують мотузками, приковують ланцюгами, пристебують наручниками. Подеколи до потерпілих від розглядуваного злочину застосовують «витончені» форми психологічного та фізичного насильства. Скажімо, у чотирьох проаналізованих випадках злочинці, привізши викраденого до лісу, змушували його копати собі яму і лягати в неї18. Одного 3 потерпілих примушували зайти до металевого вольєра, в якому знаходилась собака бійцівської породи; коли чоловік відмовився, його силою заштовхали у вольєр і зачинили двері, а потім нацькували собаку на нього 19 . Іноді ж викрадачі демонструють дива вигадливості, прагнучи раз і назавжди провчити незгідливу людину чи людину, що серйозно, на їх погляд, провинилася. У даному контексті вирізняється кримінальне провадження, розглянуте Ірпінським міським судом Київської області у січні 2018 року. Група осіб, діючи на замовлення бізнесмена, який мав конфлікт з іншим місцевим підприємцем, силоміць помістила останнього до салону автомобіля, де за допомогою клейкої стрічки з полімерного матеріалу йому зв'язали руки та ноги, закрили очі, натягнувши на голову шерстяну шапку, після чого перевезли до гаража та помістили в заздалегідь придбану для цього труну, в якій попередньо зробили отвори для дихання, а кришку домовини забили цвяхами ${ }^{20}$.

Інтерес становить також інформація про причини, завдяки яким жертви розглядуваного злочину були звільнені. Відповідна інформація отримана нами щодо 345 потерпілих. Найбільше, 40,6 \% осіб, звільнено працівниками правоохоронних органів. Найчастіше правоохоронці повертали свободу потерпілим, утримуваним протягом тривалого часу, а також викраденим малолітнім. Майже стільки ж (36,8 \%) злочинці, досягши поставленої мети (провчити, налякати, отримати обіцянку швидкого повернення боргу тощо), відпустили або ж залишили на місці, куди перемістили. Зауважимо, що іноді викрадачі не просто відпускають потерпілу особу, а відвозять їі на місце, де захопили, або ж навіть привозять додому. 13,3% потерпілих зуміли звільнитись чи втекти завдяки недостатньо продуманим винними умовам утримання (зуміли відчинити двері, розв'язати мотузку та ін.), втратою ними на якийсь час пильності тощо. 2,6 \% потерпілих звільнені їхніми батьками чи іншими родичами, представниками соціальних служб. 4 \% жертв внаслідок застосованого щодо них фізичного насильства померли, ще 2,6 \% - зникли безвісти.

Одним із факторів вчинення незаконного позбавлення волі або викрадення людини виступає віктимна поведінка жертви даного злочину. Найбільш поширену поведінку жертв розглядуваного посягання, на наш погляд, можна класифікувати на неправомірну, асоціальну, нейтральну, необачну та суспільно корисну (виокремлені типи поведінки, зрозуміло, можуть перетинатися).

До незаконного позбавлення волі або викрадення людини доволі часто призводить неправомірна поведінка жертви, зокрема вчинення нею кримінально караного діяння. У нашому випадку такими діяннями найчастіше є крадіжка та заподіяння тілесних ушкоджень. Втративши певне майно, потерпіла особа іноді бажає якомога швидше самотужки покарати винного (нерідко гаданого), отримати від нього відповідне зізнання або ж примусити його повернути викрадене майно шляхом незаконного позбавлення волі чи викрадення людини. Ілюстрацією до сказаного може бути така фабула розглянутого Корабельним районним судом м. Миколаєва кримінального провадження: вирішивши самостійно провчити знайомого, який вчинив крадіжку належного йому майна, а міліція адекватно не відреагувала на написану заяву, чоловік силою примусив крадія сісти в авто і відвіз його до свого домоволодіння, де понад добу незаконно утримував у приміщенні гаража 21 . Так само і потерпіла від побоїв чи тілесних ушкоджень особа, розчарувавшись у можливостях правоохоронної системи, подеколи вирішує незаконно позбавити свого кривдника волі, помстившись йому таким чином за заподіяну шкоду. Однак найчастіше поштовхом до вчинення розглядуваного злочину є ухилення потерпілих від виконання своїх цивільно-правових зобов'язань. Зазначимо, що борг іноді зовсім невеликий, однак винні вважають «справою принципу» не тільки повернути свої гроші, а й покарати за несвоєчасне їх повернення. Так, Іллічівський районний суд м. Маріуполя Донецької області 10 травня 2012 р. засудив жінку, яка, перебуваючи у стані алкогольного сп'яніння, вирішила покарати свою знайому, що заборгувала їй 16 гривень. 3 цією метою вона змусила її спуститися в підвальне приміщення літньої кухні, де протягом кількох годин незаконно утримувала22. Утім, аналіз судової практики засвідчує, що сума боргу, який не повертала потерпіла особа, іноді була незрівнянно більшою. Відповідні кошти ставали причиною конфлікту між підприсмцями, окремі з яких вдавалися до набагато серйозніших кроків, аби нарешті повернути заборговане. Судячи з порівняної поширеності відповідної практики, незаконне позбавлення волі або викрадення боржника розглядається винними як ефективний спосіб повернення боргу.

Варто зазначити, що неправомірна поведінка - єдина поведінка жертви, яку суди рідко, але враховують при призначенні покарання винному. Так, наприклад, Баришівський районний суд Київської області, засудивши учасників групи осіб, які викрали підприємця і незаконно утримували його на території садового господарства, де примушували до виконання цивільно-правового зобов'язання, підкреслив, що він враховує вік- 
тимну поведінку самого потерпілого, який ухилявся від зустрічей з кредитором і не бажав остаточно передати у власність літак АН-26, що у підсумку й призвело до його викрадення та настання тяжких наслідків (загибелі) ${ }^{23}$.

Асоціальна поведінка жертв даного злочину пов'язана передовсім із зловживанням ними алкогольними напоями та загалом аморальним способом життя. Зрозуміло, що саме по собі перебування особи у стані сп'яніння полегшує вчинення щодо неї незаконного позбавлення волі чи ії викрадення, оскільки зменшує можливості для ефективного опору. Підкреслимо також, що розглядуваному злочину нерідко передує спільне із злочинцями розпивання спиртних напоїв. Під час пиятики добряче підігріті алкоголем «товариші по чарці» згадують потерпілим навіть давні та зовсім дрібні проступки і образи, які й стають приводом виникнення конфлікту. Нерідко тільки випадок визначає, хто із сторін конфлікту стане злочинцем, а хто - жертвою. Ілюстрацією до сказаного є така фабула архівної кримінальної справи: група осіб, вживши на трьох майже дві літри горілки, пригадала одній із учасниць застілля, що вона била свою племінницю, коли та була дитиною. Вирішивши поквитатися 3 тіткою за давні образи, племінниця схопила кухонного ножа і порізала родичці живіт, а потім разом із товаришем по чарці роздягнула її догола, зв'язала руки за спиною і зачинила в погребі, у якому потерпіла перебувала протягом двох годин ${ }^{24}$.

Під час вивчення доступної емпіричної бази автор цих рядків виявив два кримінальні провадження, що стосувалися заволодіння житлом самотніх осіб, які зловживали спиртним, шляхом викрадення та незаконного позбавлення їх волі. Так, Дніпровський районний суд м. Києва 15 червня 2015 р. засудив двох співучасників, які, представившись чоловікові, який систематично зловживав алкоголем, працівниками міліції, вивели його з квартири і на автомобілі повезли у невідомому для нього напрямку у заздалегідь підготовлене місце, де незаконно утримували 3 метою заволодіти його квартирою. Потерпілому постійно пропонували алкогольні напої, аби він не загострював увагу на «зайвих» моментах, вивозили до державних установ збирати документи для продажу свого помешкання за явно заниженою ціною. Втекти від злочинців він не намагався, оскільки вважав їх працівниками міліції 25 . У наведеному та іншому 26 випадках розкрити злочин вдалося лише завдяки пильності небайдужих сусідів та родичів, які вчасно вдарили на сполох. Немає сумнівів у тому, що подібних випадків в об'єктивній дійсності немало. Вчиненню відповідних злочинів сприяє також те, що алкозалежній особі притаманні такі риси як надмірна довірливість, некритичність, жадібність, низький культурний та освітній рівень. Поєднуючись, ці якості за певних обставин можуть сприяти вчиненню злочину. Злочинці враховують, ким є вибрана ними жертва, визначають їі слабкі сторони та якості, які можна використати у власних протиправних цілях.

Варто зазначити, що жертвами розглядуваного злочину іноді стають не тільки алкозалежні, а й інші особи, які ведуть аморальний спосіб життя. Приміром, Шевченківський районний суд м. Києва під час судового розгляду встановив, що група осіб, діючи за попередньою змовою, з невстановлених мотивів, вирішила викрасти та незаконно позбавити волі двох жінок, які надають послуги сексуального характеру за грошову винагороду. 3 цією метою чоловіки знайшли в інтернеті оголошення з пропозицією надання секс-послуг $\mathrm{i}$ зателефонували за вказаним у ньому номером телефону. Коли проститутки прибули до обумовленого місця, їх схопили за руки i, застосовуючи фізичне насильство, повели до автомобіля. Оцінивши ситуацію, одна із жінок змогла вирватись і сісти в таксі, іншу ж посадили в авто і привезли до квартири, у якій всупереч ії волі утримували понад добу27. У спеціальній літературі раніше слушно підкреслювалось, що особи, котрі за грошову винагороду надають послуги сексуального характеру, мають підвищений ризик стати жертвою низки злочинів ${ }^{28}$. Одним із таких злочинів, поза сумнівом, є незаконне позбавлення волі або викрадення людини.

При вивченні матеріалів кримінальних проваджень порівняно часто трапляється нейтральна поведінка жертв розглядуваного злочину, тобто така, що не сприяла його вчиненню. Так, наприклад, Сумський районний суд Сумської області 29 червня 2011 р. засудив трьох співучасників, які, перебуваючи в стані сильного алкогольного сп'яніння, викликали таксі, а потім, погрожуючи водієві застосуванням фізичного насильства, наказали йому вийти з автомобіля, відчинити багажник та лягти в нього, після чого близько години возили територією Сумського району29. Маємо також підстави стверджувати, що нейтральна поведінка характерна принаймні для частини жертв незаконного позбавлення волі як виду домашнього насильства.

Необачна (легковажна) поведінка найчастіше трапляється при викраденнях малолітніх дітей i пов'язана передовсім з тим, що жертви даного злочину перебували без нагляду дорослих. Так, наприклад, Оболонський районний суд м. Києва засудив жінку, яка помітивши, що батько залишив без нагляду дитину, котра перебувала в колясці і переконавшись, що за ії діями ніхто не спостерігає, схопила переносну дитячу сумку з малолітньою дитиною та 3 місця вчинення злочину зникла ${ }^{30}$. Необачна поведінка жертв розглядуваного злочину полягає також у надмірній довірливості стороннім особам (наприклад, хизування їм своїми статками).

Суспільно корисна (позитивна) поведінка жертв незаконного позбавлення волі або викрадення людини трапляється найрідше. Її прикладом, на наш погляд, можуть слугувати дії чоловіка, який у цілком коректній формі зробив зауваження трьом особам, які грубо порушили правила дорожнього руху. У відповідь вказані особи, згодом засуджені Сокальським районним судом Львівської області, насильно помістили чоловіка в багажник автомобіля і вивезли у лісовий масив на околиці району, де, прагнучи провчити за зухвалість, заподіяли йому легкі тілесні ушкодження, що спричинили короткочасний розлад здоров'я31.

Варто підкреслити, що наслідки незаконного позбавлення волі або викрадення людини для потерпілої особи можуть бути різноманітними: отримання різного ступеня тяжкості тілесних ушкоджень та (або) пси- 
хічних травм, заподіяння матеріальної та (чи) моральної шкоди тощо. У зв’язку з цим зазначимо, що в рамках кримінального провадження потерпілі від розглядуваного злочину далеко не завжди заявляють цивільний позов про відшкодування завданої їм матеріальної та (чи) моральної шкоди. У тих випадках, коли відповідний позов заявлено (орієнтовно 30 \%), суди переважно задовольняють його повністю або частково (значно частіше). Зауважимо також, що суди досить часто враховують позицію потерпілих щодо призначення покарання винним. Як правило, потерпілі просять суд не призначати засудженим покарання у виді позбавлення волі на певний строк, нерідко вважають за доцільне звільнити винного від відбування покарання 3 випробуванням. Так, наприклад, потерпіла співмешканка неодноразово судимого чоловіка, який, перебуваючи в стані алкогольного сп’яніння, понад годину незаконно утримував їі в квартирі, просила суд суворо не карати підсудного, оскільки злочин він вчинив на грунті ревнощів, підстави для чого дала вона сама 32 .

Підсумовуючи викладене, підкреслимо, що особа жертви незаконного позбавлення волі або викрадення людини відіграє важливе значення у механізмі вчинення даного злочину. 3 огляду на це у системі заходів запобігання вказаним посяганням віктимологічна профілактика повинна займати особливе місце.

1 Архів Орджонікідзевського районного суду м. Запоріжжя за 2018 рік. Справа № 335/2131/18.

2 Бауськов Д.Г. Уголовно-правовая и криминологическая характеристика насильственного похищения человека: дисс. ... канд. юрид. наук: 12.00.08. Москва, 2003. С. 40; Карасёва М.Ю. Уголовная ответственность за преступления против свободы личности: дисс. ... канд. юрид. наук: 12.00.08. Москва, 2007. С. 160; Ушакова Е.В. Уголовно-правовые и криминологические меры противодействия похищения человеку: дисс. ... канд. юрид. наук: 12.00.08. Москва, 2012. С. 140.

3 Архів Солом'янського районного суду м. Києва за 2013 рік. Справа № 760/25524/13-к.

4 Див. детальніше: Андрушко А.В. Незаконне позбавлення волі як вид домашнього насильства (кримінологічний аспект). Організаиійно-правові засади запобігання домашньому насильству: реалії та перспективи: матеріали круглого столу, 31 травня 2019 р. / за ред. О.П. Рябчинської. Запоріжжя: КПУ, 2019. С. 18-22.

5 Голина В.В., Батыргареева В.С. Проблемы борьбы с преступлениями против личной свободы человека в Украине. Проблеми законності: респ. міжвідом. наук. зб. Харків, 2001. Вип. 49. С. 136.

6 Ушакова Е.В. Уголовно-правовые и криминологические меры противодействия похищения человеку: дисс. ... канд. юрид. наук: 12.00.08. Москва, 2012. С. 141.

7 Карасёва М.Ю. Уголовная ответственность за преступления против свободы личности: дисс. ... канд. юрид. наук: 12.00.08. Москва, 2007. С. 156-157.

8 Филин М.В. Уголовная ответственность за незаконное лишение человека свободы: дисс. ... канд. юрид. наук: 12.00 .08$. Хабаровск, 2000. С. 172.

9 Архів Першотравневого районного суду м. Чернівці за 2013 рік. Справа № 725/638/13-к.

10 Архів Придніпровського районного суду м. Черкаси за 2013 рік. Справа № 711/4314/13-к.

11 Архів Дніпропетровського районного суду Дніпропетровської обл. за 2017 рік. Справа № 175/5178/15-к; Архів Ізмаїльського міськрайонного суду Одеської обл. за 2017 рік. Справа № 500/4723/17.

12 Архів Черняхівського районного суду Житомирської обл. за 2012 рік. Справа № 1/0624/117/2012.

13 Архів Марківського районного суду Луганської обл. за 2018 рік. Справа № 417/5332/18.

14 Архів Вишгородського районного суду Київської обл. за 2018 рік. Справа № 363/1843/18.

15 Архів Генічеського районного суду Херсонської обл. за 2015 рік. Справа № 653/2988/15-к.

16 Архів Орджонікідзевського районного суду м. Запоріжжя за 2018 рік. Справа № 335/2131/18.

17 Архів Ленінського районного суду м. Запоріжжя за 2015 рік. Справа № 334/10243/15-к.

18 Архів Лубенського міськрайонного суду Полтавської обл. за 2013 рік. Справа № 539/218/13-к; Архів Маловисківського районного суду Кіровоградської обл. за 2013 рік. Справа № 392/1527/13-к; Архів Теребовлянського районного суду Тернопільської обл. за 2015 рік. Справа № 606/1469/15-к; Архів Андрушівського районного суду Житомирської обл. за 2017 рік. Справа № 272/578/16-к.

19 Архів Сєверодонецького міського суду Луганської обл. за 2012 рік. Справа № 1-652/11.

20 Архів Ірпінського міського суду Київської обл. за 2018 рік. Справа № 367/7368/15-к.

21 Архів Корабельного районного суду м. Миколаєва за 2016 рік. Справа № 488/3177/15-к.

22 Архів Іллічівського районного суду м. Маріуполя Донецької обл. за 2012 рік. Справа № 0520/4336/2012.

23 Архів Баришівського районного суду Київської обл. за 2011 рік. Справа № 1-89/11.

24 Архів Артемівського міськрайонного суду Донецької обл. за 2012 рік. Справа № 1-282/2011.

25 Архів Дніпровського районного суду м. Києва за 2015 рік. Справа № 755/13814/14-к.

26 Архів Жовтневого районного суду м. Луганська за 2013 рік. Справа № 1-828/11.

27 Архів Шевченківського районного суду м. Києва за 2018 рік. Справа № 761/7009/17.

28 Кримінологічна віктимологія: навч. посіб. / за заг. ред. проф. О.М. Джужі. Київ: Атіка, 2006. С. 290.

29 Архів Сумського районного суду Сумської обл. за 2011 рік. Справа № 1-47/11.

30 Архів Оболонського районного суду м. Києва за 2018 рік. Справа № 756/2379/18.

31 Архів Сокальського районного суду Львівської обл. за 2013 рік. Справа № 454/2501/13-к.

32 Архів Авдіївського міського суду Донецької обл. за 2011 рік. Справа № 1-223/11.

\section{References:}

Arkhiv Ordzhonikidzevs'koho rajonnoho sudu m. Zaporizhzhia (2018). Sprava № 335/2131/18 [in Ukrainian].

Bauskov, D.G. (2003). Ugolovno-pravovaya i kriminologicheskaya harakteristika nasilstvennogo pohischeniya cheloveka: diss. ... kand. yurid. nauk: 12.00.08. Moskva [in Russian]; Karasyova, M.Yu. (2007). Ugolovnaya otvetstvennost za prestupleniya protiv svobodyi lichnosti: diss. ... kand. yurid. nauk: 12.00.08. Moskva [in Russian]; Ushakova, E.V. (2012). Ugolovno-pravovyie i kriminologicheskie meryi protivodeystviya pohischeniya cheloveku: diss. ... kand. yurid. nauk: 12.00.08. Moskva [in Russian].

Arkhiv Solom'ians'koho rajonnoho sudu m. Kyieva (2013). Sprava № 760/25524/13-k [in Ukrainian]. 
Andrushko, A.V. (2019). Nezakonne pozbavlennia voli iak vyd domashn'oho nasyl'stva (kryminolohichnyj aspekt). Orhanizatsijno-pravovi zasady zapobihannia domashn'omu nasyl'stvu: realii ta perspektyvy: materialy kruhloho stolu, 31 travnia 2019 r. / za red. O.P. Riabchyns'koi. Zaporizhzhia: KPU [in Ukrainian].

Golina, V.V., Batyirgareeva, V.S. (2001). Problemyi borbyi s prestupleniyami protiv lichnoy svobodyi cheloveka v Ukraine. Problemy zakonnosti: resp. mizhvidom. nauk. zb. Harkiv, Vyp. 49 [in Russian].

Ushakova, E.V. (2012). Ugolovno-pravovyie i kriminologicheskie meryi protivodeystviya pohischeniya cheloveku: diss. ... kand. yurid. nauk: 12.00.08. Moskva [in Russian].

Karasyova, M.Yu. (2007). Ugolovnaya otvetstvennost za prestupleniya protiv svobodyi lichnosti: diss. ... kand. yurid. nauk: 12.00.08. Moskva [in Russian].

Filin, M.V. (2000). Ugolovnaya otvetstvennost za nezakonnoe lishenie cheloveka svobodyi: diss. ... kand. yurid. nauk: 12.00 .08$. Habarovsk [in Russian].

Arkhiv Pershotravnevoho rajonnoho sudu m. Chernivtsi (2013). Sprava № 725/638/13-k [in Ukrainian].

Arkhiv Prydniprovs'koho rajonnoho sudu m. Cherkasy (2013). Sprava № 711/4314/13-k [in Ukrainian].

Arkhiv Dnipropetrovs'koho rajonnoho sudu Dnipropetrovs'koi obl. (2017). Sprava № 175/5178/15-k [in Ukrainian]; Arkhiv

Izmail's'koho mis'krajonnoho sudu Odes'koi obl. (2017). Sprava № 500/4723/17 [in Ukrainian].

Arkhiv Cherniakhivs'koho rajonnoho sudu Zhytomyrs'koi obl. (2012). Sprava № 1/0624/117/2012 [in Ukrainian].

Arkhiv Markivs'koho rajonnoho sudu Luhans'koi obl. (2018). Sprava № 417/5332/18 [in Ukrainian].

Arkhiv Vyshhorods'koho rajonnoho sudu Kyivs'koi obl. (2018). Sprava № 363/1843/18 [in Ukrainian].

Arkhiv Heniches'koho rajonnoho sudu Khersons’koi obl. (2015). Sprava № 653/2988/15-k [in Ukrainian].

Arkhiv Ordzhonikidzevs'koho rajonnoho sudu m. Zaporizhzhia (2018). Sprava № 335/2131/18 [in Ukrainian].

Arkhiv Lenins’koho rajonnoho sudu m. Zaporizhzhia (2015). Sprava № 334/10243/15-k [in Ukrainian].

Arkhiv Lubens'koho mis'krajonnoho sudu Poltavs'koi obl. (2013). Sprava № 539/218/13-k [in Ukrainian]; Arkhiv Malovyskivs'koho rajonnoho sudu Kirovohrads'koi obl. (2013). Sprava № 392/1527/13-k [in Ukrainian]; Arkhiv Terebovlians'koho rajonnoho sudu Ternopil's'koi obl. (2015). Sprava № 606/1469/15-k [in Ukrainian]; Arkhiv Andrushivs'koho rajonnoho sudu Zhytomyrs'koi obl. (2017). Sprava № 272/578/16-k [in Ukrainian].

Arkhiv Sieverodonets'koho mis'koho sudu Luhans'koi obl. (2012). Sprava № 1-652/11 [in Ukrainian].

Arkhiv Irpins'koho mis’koho sudu Kyivs'koi obl. (2018). Sprava № 367/7368/15-k [in Ukrainian].

Arkhiv Korabel'noho rajonnoho sudu m. Mykolaieva (2016). Sprava № 488/3177/15-k [in Ukrainian].

Arkhiv Illichivs'koho rajonnoho sudu m. Mariupolia Donets’koi obl. (2012). Sprava № 0520/4336/2012 [in Ukrainian].

Arkhiv Baryshivs'koho rajonnoho sudu Kyivs'koi obl. (2011). Sprava № 1-89/11 [in Ukrainian].

Arkhiv Artemivs'koho mis'krajonnoho sudu Donets'koi obl. (2012). Sprava № 1-282/2011 [in Ukrainian].

Arkhiv Dniprovs’koho rajonnoho sudu m. Kyieva (2015). Sprava № 755/13814/14-k [in Ukrainian].

Arkhiv Zhovtnevoho rajonnoho sudu m. Luhans'ka (2013). Sprava № 1-828/11 [in Ukrainian].

Arkhiv Shevchenkivs'koho rajonnoho sudu m. Kyieva (2018). Sprava № 761/7009/17 [in Ukrainian].

Dzhuzha O.M. (Red.). (2006). Kryminolohichna viktymolohiia: navch. posibnyk. Kyiv: Atika [in Ukrainian].

Arkhiv Sums'koho rajonnoho sudu Sums'koi obl. (2011). Sprava № 1-47/11 [in Ukrainian].

Arkhiv Obolons'koho rajonnoho sudu m. Kyieva (2018). Sprava № 756/2379/18 [in Ukrainian].

Arkhiv Sokal's'koho rajonnoho sudu L'vivs'koi obl. (2013). Sprava № 454/2501/13-k [in Ukrainian].

Arkhiv Avdiivs'koho mis'koho sudu Donets'koi obl. (2011). Sprava № 1-223/11 [in Ukrainian].

\section{Резюме}

Андрушко А.В. Віктимологічна характеристика жертв незаконного позбавлення волі або викрадення людини.

У статті на підставі аналізу доступної емпіричної бази розроблено віктимологічну характеристику жертв незаконного позбавлення волі або викрадення людини (ст. 146 КК України) та з'ясовано особливості віктимної поведінки потерпілих від вказаного злочину. Зроблено висновок про те, що особа жертви незаконного позбавлення волі або викрадення людини відіграє важливе значення у механізмі вчинення даного посягання.

Ключові слова: злочини проти волі, честі та гідності особи, незаконне позбавлення волі, викрадення людини, жертва злочину, віктимологічна характеристика, віктимна поведінка.

\section{Резюме}

Андрушко А.В. Виктимологическая характеристика жертв незаконного лишения свободы или похищения человека.

В статье на основании анализа доступной эмпирической базы разработана виктимологическая характеристика жертв незаконного лишения свободы или похищения человека (ст. 146 Уголовного кодекса Украины) и выяснены особенности виктимного поведения потерпевших от указанного преступления. Сделан вывод о том, что личность жертвы незаконного лишения свободы или похищения человека имеет большое значение в механизме совершения данного посягательства.

Ключевые слова: преступления против свободы, чести и достоинства личности, незаконное лишение свободы, похищение человека, жертва преступления, виктимологическая характеристика, виктимное поведение.

\section{Summary}

Andriy Andrushko. Victimological profile of victims of unlawful deprivation of liberty or abduction.

The article researches on the existing empirical data and provides a victimological profile of victims of unlawful deprivation of liberty and abduction (art. 146 of the Criminal Code of Ukraine) and reveals peculiarities of victim behavior of victims of these crimes.

The author has analyzed 370 criminal cases (proceedings) on unlawful deprivation of liberty or abduction reviewed by courts of Ukraine in 2010-2018. Data on 447 victims of such crimes were summarized.

In most cases, the crimes in question were committed against one person. Among victims $69,6 \%$ were male and $30,4 \%$ female. As regards the age of victims, $14,1 \%$ of them were under 18 years old (including 9,8\% of juveniles), 29,4 \% - 18 to 30 years old, 
$33,7 \%-30$ to 40 years old, $16,3 \%-40-50$ years old, $6,5 \%$ - over 50 years old. Only 2 of $447(0,4 \%)$ victims were not citizens of Ukraine. Only $29 \%$ of victims were married (officially or de facto). However, the article emphasizes that the crimes in question are frequently committed in the context of family and domestic relations. Among the victims of unlawful deprivation of liberty or abduction $6,4 \%$ had an unfinished high school education, 49,2\% - high school education, 33,9\% - special secondary education, 10,5\% - higher education. At the moment when the crime was committed against them, $41,8 \%$ of victims were jobless or had only seasonal jobs, $39,4 \%$ were employed, $11,6 \%$ - pupils, $2,9 \%$ - retired, $4,3 \%$ entrepreneurs. Before the commitment of crimes in question, the majority of victims (near $60 \%$ ) were to a various degree acquainted with criminals (were engaged in family, marital, labor or other relations, were friends, fellow-villagers, neighbors or just knew them). The crimes in question were committed in the morning in $13,9 \%$ of cases, in the daytime in $31,8 \%$ of cases, in the evening in $37,3 \%$ of cases, and at night in $17 \%$ of cases.

People become victims of unlawful deprivation of liberty in places where they were (for example, when contrary to their will they are not allowed to leave a room or a car, are forced to stay in a house's basement, etc.). Most of the victims were captured by criminals on streets, in victims' apartments or in their vicinity.

Physical violence is frequently used towards a victim in order to unlawfully deprive a victim of liberty. As regards capturing a person and his/her abduction, physical violence happens regularly. On many occasions, physical violence is combined with psychological violence and deception.

As a rule, abducted persons are moved to short distances - mostly withing one locality (for instance, they are moved to outskirts of a town or to the nearest forest).

It is revealed in the article that in the majority of cases victims of unlawful deprivation of liberty or abduction did not resist actively.

Minimal and maximal terms victims were held by criminals vary dramatically - from 4-5 days to more than 11 months.

Unlawful withholding of victims is usually combined with causing bodily harm of different degrees, torturing, death threats, violation of human dignity.

Most typical behavior of victims of crimes in question is divided into unlawful, anti-social, neutral, incautious, and socially useful.

It concludes that a personality of a victim of unlawful deprivation of liberty and abduction plays an important (and in some particular issues - the decisive) role in the mechanism of committing this crime.

Key words: crimes against liberty, honor and dignity of the person; unlawful deprivation of liberty, abduction, victim of a crime, victimological profile, victim behavior.

DOI: $10.36695 / 2219-5521.2 .2019 .30$

удк 343.2

\section{Н.О. АНТОНЮК}

Наталія Олегівна Антонюк, кандидат юридичних наук, доцент, суддя Великої Палати Верховного Суду, доцент Львівського національного університету імені Івана Франка*

ORCID: 0000-0002-7582-2071

\section{КОНЦЕПЦІЇ РОЗУМІННЯ КРИМІНАЛЬНОЇ ВІДПОВІДАЛЬНОСТІ}

Постановка проблеми Поняття кримінальної відповідальності досі залишається дискусійним у наукових дослідженнях. Правильне встановлення змісту цього поняття є актуальним з огляду на використання відповідного терміна у нормативних конструкціях Кримінального кодексу України, як-от «підстава кримінальної відповідальності», «звільнення від кримінальної відповідальності» тощо. Також дефініція кримінальної відповідальності має важливе значення для встановлення змісту таких правових категорій, як «диференціація кримінальної відповідальності», «індивідуалізація кримінальної відповідальності» та ін.

Аналіз останніх досліджень і публікацій. У науці кримінального права налічується близько десяти різноманітних концепцій поняття кримінальної відповідальності. За радянського періоду цю проблему вивчали такі науковці, як: О.І. Бойцов, Я.М. Брайнін, М.І. Загородніков, М.П. Карпушин, С.Г. Келіна, B.I. Курляндський, О.Е. Лейст, А.І. Марцев, А.І. Санталов та інші. Серед українських дослідників над цією проблематикою працювали Ю.В. Баулін, В.К. Грищук, О.О. Кваша, М.І. Панов, Ю.А. Пономаренко, М.І. Хавронюк та інші вчені. Проте дискусійними залишаються не лише поняття кримінальної відповідальності, але й визначення моменту ії початку та закінчення.

Формулювання мети статті. Метою цієї статті є дослідження концепцій сутності кримінальної відповідальності, критичний аналіз змістовних ознак цієї категорії. Кінцевим результатом аналізу таких концепцій $є$ формулювання ознак, якими повинна характеризуватися кримінальна відповідальність, як кримінально-правове явище.

Виклад основного матеріалу дослідження. Розпочнемо 3 того, що чинний Кримінальний кодекс України (далі - КК України) не містить такого поняття, як «кримінальна відповідальність». Водночас цей

\section{(C) Н.O. Антонюк, 2019}

* Natalia Antoniuk, Ph.D. in Law, Associate professor, Associate professor of Ivan Franko National University of Lviv, Judge of Great Chamber of the Supreme Court 